\title{
TRADE-UNION POLICY BETWEEN THE WARS
}

\author{
THE CASE OF HOLIDAYS WITH PAY IN BRITAIN*
}

Most standard histories of Britain between the wars refer to the development of holidays with pay, albeit briefly. It is widely acknowledged that by the end of the 1930's the majority of the British working population benefited from a paid holiday. The crucial initiative, so it is claimed, was the Holidays with Pay Act of 1938, which gave Parliamentary approval to the principle of payment of wages during holidays. ${ }^{1}$ Clearly the growth of paid holidays is seen as yet another instance of a more affluent Britain, an integral element of the growth of leisure. ${ }^{2}$ However, there has been very little detailed discussion of the paid-holiday-policy option and the precise reasons for the formulation and implementation of that policy. This neglect is rather surprising given the popular support for this "fringe benefit", which was perceived as providing a certain degree of financial security during the annual break from the rigours of work. It is true that there has been more specialised treatment, but even this is of a general nature, with little reference to the industrial and political struggle for holidays with pay. ${ }^{3}$

* I would like to thank Dr M. E. Rose, Professor A. E. Musson and members of the Editorial Board for their helpful comments.

${ }^{1}$ See C. L. Mowat, Britain Between the Wars 1918-1940 (London, 1955), p. 501; D. H. Aldcroft, The Inter-War Economy: Britain, 1919-1939 (London, 1970), p. 366; N. Branson and M. Heinemann, Britain in the Nineteen Thirties (St Albans, 1973), pp. 93-94; A. J. P. Taylor, English History 1914-1945 (London, 1977), p. 305; J. Stevenson, British Society 1914-45 (Harmondsworth, 1984), p. 193. This paper will argue that the Holidays with Pay Act was insignificant as compared with the growth of appropriate collective agreements.

2 J. Stevenson and Ch. Cook, The Slump: Society and Politics during the Depression (London, 1977), pp. 25-26. For the growth of leisure, see S. G. Jones, "The Leisure Industry in Britain, 1918-1939", in: The Service Industries Journal, V (1985); id., Workers At Play: A Social and Economic History of Leisure, 1918-1939 (forthcoming, 1986).

3 J. A. R. Pimlott, The Englishman's Holiday: A Social History (London, 1947), pp. 21137; G. C. Cameron, "The Growth of Holidays with Pay in Britain", in: Fringe Benefits, 
Paid holidays was one of the main trade-union demands of the interwar years, the point of a well-orchestrated campaign which hitherto has received little attention from labour historians. As this case-study will show the question of holidays with pay was a salient union issue, frequently raised at conferences and in negotiations with employers, and even the centre of industrial action. This is not to argue, of course, that the demand was at the forefront of industrial and political agitation. A progressive claim of this nature was often shelved as union strength was depleted by rising unemployment, and struggles were waged in the defence of more fundamental conditions. Indeed, the question needs to be posed at the outset: how did paid holidays compare with other objectives of the trade-union movement? The purpose of this paper is therefore to focus on the role played by the trade unions in the articulation of and the campaign for this important reform, and to assess the position taken up by the other main sectional interests. But first of all, there is a need to provide an overview of the main developments.

\section{The growth of paid holidays}

Before the First World War the idea of a paid holiday had not gained general credence. In a period when the unions were struggling for elementary social, political and industrial justice, holiday pay was probably regarded as somewhat Utopian. Nevertheless, many of the lower middle classes received payment during holidays: clerks in the larger industrial and commercial concerns, employees of banks and insurance companies, and administrative staff. ${ }^{4}$ Moreover, holidays with pay for manual workers were not unknown. As early as 1840, the South Metropolitan Gas Company had granted wages on Good Friday and Christmas Day; and from 1860 a week's holiday pay was given to all workers in constant employment. ${ }^{5} \mathrm{By}$ the 1890's firms such as Brunner Mond, Lever Brothers, the Gas Light and Coke Company, and industrial establishments such as the London and North Western Railway Company and the Royal Dockyards had followed suit. ${ }^{6}$ According to the General Secretary of the Thames Labour Protection

Labour Costs and Social Security, ed. by G. L. Reid and D. J. Robertson (London, 1965); G. C. Martin, "Some Aspects of the Provision of Annual Holidays for the English Working Classes down to 1947”' (M.A., Leicester University, 1968), pp. 61-67, 83-89.

${ }^{4}$ Pimlott, The Englishman's Holiday, p. 154.

5 Royal Commission on Labour: Minutes of Evidence, Group C, III (1893), q. 26710.

${ }^{6} \mathrm{E}$. H. Ph. Brown, The Growth of British Industrial Relations: A Study from the standpoint of 1906-14 (London, 1959), pp. 77-78; Pimlott, The Englishman's Holiday, pp. 155-56. 
League paid-holiday schemes were quite common: "In many private firms holidays are paid for. I have done a good deal of work in different firms, and I have never yet worked in a firm but once where I was not paid for holidays." However, it was not unusual for leave to be deducted if the men fell sick or lost time during the year. At the end of the year few men were therefore entitled to a paid holiday. ${ }^{8}$

The ending of hostilities in 1918 witnessed an extension of relevant agreements. Towards the end of the First World War important discussions took place within the Ministry of Reconstruction, and it was here that the idea of a paid holiday gained a wider audience. In 1917 the Ministry set up a Civil War Workers' Committee, which considered and actively discussed the question. The terms of reference related to holidays for munition workers, but arguments about the wider ramifications of a paid holiday were a salient feature of discussion. The report of the Committee appeared in April 1918 and is a useful synopsis of contemporary attitudes. Although the majority came out against holidays with pay on the grounds that it "would inevitably lead to an irresistible demand for a general holiday at the expense of the state", labour representatives felt that munition workers should be granted such a benefit. ${ }^{9}$ The ambiguity of the report made it difficult for the Minister of Reconstruction, Dr Christopher Addison, to formulate a coherent policy. In September 1918 he did make recommendations for an Annual Holiday, but it seems likely that the burden of work and the lack of time prevented the Ministry from forwarding any concrete proposals. ${ }^{10}$ Nonetheless, the inactivity of the Ministry did not mean that official discussions were unimportant, for they gave expression to a demand which was gaining support.

The institutional response to the demand for paid holidays can also be recognised in trade-board legislation and official industrial-relations machinery. By the Trade Boards Act of 1918 holiday-with-pay settlements could be made, whilst National Joint Industrial Councils could deal with the rules relating to holiday arrangements. ${ }^{11}$ In addition the Councils, which had been established in certain industries at the end of the war, discussed the case for paid holidays put forward by representatives of labour. By 1920 the bodies in the flourmilling industry, in tramways, in the soap- and

7 Royal Commission on Labour: Minutes of Evidence, Group A, III (1893), q. 23769. ${ }^{8}$ Ibid., q. 23930.

${ }^{9}$ Civil War Workers' Committee, Third Interim Report: Holidays for Munition Workers After the War (1918), pp. 12-15.

${ }^{10}$ P. B. Johnson, Land Fit For Heroes: The Planning of British Reconstruction 19161919 (Chicago, 1968), pp. 187, 215.

11 Ministry of Labour, Industrial Reports, No 4 (Revised): "Industrial Councils" (London, 1920), p. 22. 
candle-manufacturing trade, and in paint and varnish manufacture had introduced a holiday with pay, usually of one week's duration. ${ }^{12}$

In more general terms, the representatives of the industrial working class had begun to articulate the demand for universal holidays. As a memorandum presented to the War Cabinet stressed, in practically all the important industries claims had been put forward for annual holidays of a week or two weeks, without loss of pay. ${ }^{13} \mathrm{By}$ the beginning of the 1920's formal agreements between employers and employees covered an estimated one million workers. There were both general and district agreements, benefiting workers in all kinds of trades ranging from railway service, public undertakings and the printing industry at the national level to co-operative societies, hairdressers and theatres at the local level. ${ }^{14}$ Although holiday arrangements did not cover all workers in these sectors and were distorted by geographical and occupational variances, they did represent a significant trade-union gain.

The immediate post-war boom broke in the spring of 1920 and by the following year Britain was experiencing an economic depression. ${ }^{15}$ In these circumstances cost increases were vigorously opposed by employers and paid holidays were not surprisingly resisted. Some agreements which had been established prior to the slump were discontinued, as in 1922 when a holiday provision for papermill workers, granted in 1920, was dropped: "The union representatives fought hard to reinstate the clause, but the employers would make no further concession." 16 In those industries under Joint Industrial Council supervision the application of holidays with pay proved difficult, and in certain instances they were suspended or postponed. ${ }^{17}$ Yet, in spite of these unfavourable conditions, the momentum of the 1919-20 period continued, so that by 1922 there were agreements covering about 1.5 million manual workers. ${ }^{18}$ This figure did not increase dramatically until the late 1930's; certain agreements lasted, others lapsed, and some were replaced. ${ }^{19}$ Nevertheless, this should not hide a number of

12 R. Charles, The Development of Industrial Relations in Britain 1911-1939 (London, 1973), pp. 166, 171, 176.

13 Cabinet Papers 24/74 (GT 6712), Public Record Office, London.

${ }_{14}$ Labour Gazette, August 1920, p. 421.

is Aldcroft, The Inter-War Economy, op. cit., pp. 36-37.

16 C. J. Bundock, The Story of the National Union of Printing, Bookbinding and Paper Workers (Oxford, 1959), p. 418.

17 Report on the Establishment and Progress of Joint Industrial Councils 1917-1922 (London, 1925), p. 96. Cf. J. B. Seymour, The Whitley Councils Scheme (London, 1932), p. 59.

18 Ministry of Labour Gazette, December 1922, pp. 474-75.

19 Ibid., March 1925, August 1929, July 1932, July 1934, April 1936. 
significant developments which kept the issue of paid holidays in the public eye: private agreements were introduced by individual firms; statutory recognition was contained in the Shops (Hours of Closing) Act, 1928; and there were a number of formal initiatives taken by the International Labour Organisation and the British Parliament. Indeed, after the trough of the depression was reached in August 1932 and the economy began to recover, the industrial and political environment was more receptive to the elaboration of social needs. Holidays with pay was again a realistic demand, culminating in 1937 in the establishment of a tripartite departmental committee of inquiry into the question.

The Holidays with Pay Committee was appointed in late March with Lord Amulree as its chairman and a number of representatives from the trade-union, business and political world. Having taken voluminous evidence from many interest groups, it reported in April 1938 in favour of the paid-holiday principle: "It cannot, in our view, be denied that an annual holiday contributes in a considerable measure to workpeople's happiness, health and efficiency and we feel that the extension of the taking of consecutive days of holiday annually by workpeople would be of benefit to the community." 20 They unanimously recommended that an annual holiday with pay "should be established, without undue delay, as part of the terms of the contract of employment." 21 In order to give the parties time for negotiation there was to be an interim or probationary period before legislation was introduced - the Committee envisaged that legislation would be passed during the Parliamentary session of 1940-41. In the mean time it was considered that statutory wage-regulating bodies should come under immediate legislation to provide them with the means of awarding holiday pay. ${ }^{22}$ The Minister of Labour, Ernest Brown, announced his intentions at the beginning of June to introduce a Holidays with Pay Bill and to set up a special "Holiday" branch in the Ministry of Labour. ${ }^{23}$ The main object of the bill was to enable trade boards, agricultural-wages committees and road-haulage central wages boards to provide paid holidays when fixing rates of wages. The proposals were not far-reaching and could only apply to a potential workforce of two million; even Brown was moved to say that "the scope of the Bill is limited." 24 In short, the Holidays with Pay Act of 1938 was not a very strong piece of legislation.

20 Report of the Committee on Holidays with Pay (1938), p. 54.

21 Ibid., p. 60.

22 Ibid., pp. 61-63. For further details, see Ministry of Labour Papers 31/1-4, Public Record Office.

${ }^{23}$ Hansard (Commons), Fifth Series, CCCXXXVI, cc. 2204-05, 2 June 1938.

${ }^{24}$ Ibid., CCCXXXVIII, c. 1553, 14 July 1938. 
Notwithstanding these developments, it was in the form of voluntary collective agreements that the majority of people came to receive a paid holiday. For instance, by April 1937 there were at least 175 individual agreements on the files of the Transport and General Workers' Union. ${ }^{25}$ More generally, when the Holidays with Pay Committee was first appointed, between 1.5 million and 1.75 million manual workers were under some kind of agreement, yet by the time the report was made the number covered by agreements had increased to about 3 million. ${ }^{26}$ This meant that 7.75 million manual and non-manual workers out of a total occupied population of 18.5 million were in receipt of holiday pay. ${ }^{27}$ Moreover, by the beginning of 1939 the number of such workers who were getting paid for their annual holiday had again increased, this time to about 11 million. ${ }^{28}$ Indeed, collective agreements had been made in many of the major industries, including engineering, mining, iron and steel manufacture, vehicle building, and transport. This was not the end of the story, however, as further gains were made during the course of the Second World War. In 1940 and 1942, for example, important agreements were finalised in the textile and building industries, respectively, so that by 1945 it was calculated that about 10 million manual workers alone were in receipt of remunerative holidays. ${ }^{29}$ It is apparent that the content of agreements varied from firm to firm and especially from industry to industry. The lack of uniformity was particularly noticeable as regards conditions of entitlement, the length of and payment for holidays, and a plethora of other provisions. Even so, the gains made between 1918 and 1939 were considerable and, perhaps even more important, by the latter date the principle of holidays with pay had been accepted by the majority of the British people. Having outlined the main developments, it is now possible to consider the policy position of the unions and the employers.

\section{The policy of the unions and the employers}

From the work of John Walton it is clear that the traditional working-class seaside-holiday had been established in Lancashire and parts of Yorkshire,

\footnotetext{
${ }^{25}$ Holidays with Pay Memorandum, 23 April 1937, Modern Records Centre, University of Warwick, Coventry (hereafter MRC), Mss 126/EB/HP/1/27.

${ }^{26}$ Minutes of Evidence Taken Before the Committee on Holidays with Pay (1937-38), p.

2; Ministry of Labour Gazette, March 1938, p. 86.

27 Report of the Committee on Holidays with Pay, p. 21.

28 Mowat, Britain Between the Wars, op. cit., p. 501. See also Ministry of Labour, Holidays with Pay: Collective Agreements Between Organisations of Employers and Workpeople (London, 1939).

${ }^{29}$ International Labour Review, LI (1945), p. 741.
} 
though not in Southern England, during the nineteenth century. Connected with the coming of the railways, an increase in wages and savings, the growth of resort facilities, and the standardisation of customary holidays, the seaside-holiday habit was "deeply rooted in the Lancashire textile district by the turn of the century".$^{30}$ Yet, although the holiday habit spread during the inter-war years, it should be emphasised that a considerable section of the working class did not have an annual break away from home. In 1937 , for example, only 15 million out of a population of 46 million were taking a holiday of one week or more.$^{31}$ The main reason for this state of affairs was, of course, that the "cost of holidays was too high for many working people." ${ }^{32}$ In effect this meant that numerous families did not have enough money to finance a holiday. Even where there was an established custom of holiday thrift clubs, economic depression, short-time working, and unemployment reduced the propensity to save, so that the amount distributed by the Oldham clubs, for instance, fell from $£ 247,804$ in 1925 to $£ 138,571$ in $1933 .{ }^{33}$ The evidence for other textile towns tells much the same story. Indeed, the holiday savings were often "used to buy clothing, to pay debts, to "straighten up things", and not for the stated purpose. ${ }^{34}$ For some families the only way to afford a day or more at the seaside was by borrowing from special holiday-loan clubs and pawnbrokers, or by illegal means through dodging ticket inspectors. ${ }^{35}$ In short, the main variable in the demand for working-class holidays was the level of financial security.

The trade unions pointed out that despite the talk of a roaring holiday trade, the holiday advertisements on every hoarding, and the headlines about record holiday traffic, the term "holiday" was a misnomer for the majority of the working class. ${ }^{36}$ As Lansbury's Labour Weekly argued, many thousands of workers had no cause to rejoice holidays as this was a time without wages, when all that could be expected was activity "in and about the streets in which they live". ${ }^{37}$ The union case was thus based on the

30 J. K. Walton, "Holidays and the Discipline of Industrial Labour: A Historian's View", in: Leisure and Urban Society, ed. by M. A. Smith (Salford, 1978); id., "The Demand for Working-Class Seaside Holidays in Victorian England", in: Economic History Review, Second Series, XXXIV (1981); id., The English Seaside Resort: A Social History 17501914 (Leicester, 1983), pp. 5-44.

${ }^{31}$ E. Brunner, Holiday Making and the Holiday Trades (Oxford, 1945), p. 3.

32 The Economist, 4 June 1938, p. 528.

33 Oldham Chronicle, 30 August 1929, 25 August 1939.

34 Cotton Factory Times, 12 August 1932.

${ }_{35}$ M. Tebbutt, Making Ends Meet: Pawnbroking and Working-Class Credit (Leicester, 1983), p. 32; S. Humphries, Hooligans or Rebels? An Oral History of Working-Class Childhood and Youth 1889-1939 (Oxford, 1981), p. 166.

36 See Daily Herald, 27 July 1920.

${ }^{37}$ Lansbury's Labour Weekly, 17 April 1926, 11 June and 9 July 1927. 
premise that many sections of the community "who need a holiday are unable to afford the cost. Some of them are unemployed; some are working casually; some are deterred by adversity; and some with large families and a constant struggle cannot accumulate the money for the fares." ${ }^{38}$ Holidays without wages were dreaded in a lot of households "because of the hardships involved", and even when full-time working was the norm, financial commitments were sometimes "too great to permit a weekly saving to meet the expenses of a blank pay day"..$^{39}$

There were also a number of further elements in the union case. Firstly, labour argued that remuneration was important as a source of relaxation, rest and recuperation - a time for utilising leisure for pleasure and health..$^{40}$ Secondly, it was pointed out that holidays should be introduced because it was the practice in many other countries, and, as the South Wales Miners' Federation protested, it was clearly unfair that manual workers did not receive these benefits, while white-collar workers did.

We see no reason why the men who usually do the hard physical work of our community, and who are generally paid the least wages, should be treated in this respect less favourably than are men who are usually much better remunerated, who are generally employed in more congenial work, and who live under more pleasant surroundings. ${ }^{41}$

Thirdly, some trade unionists believed that paid leave could act as a remedy for unemployment by sharing the available work more evenly among the population of working age. ${ }^{42}$ Many other arguments were used, but in the main the unions presented a case for holidays with pay in response to the hardships created by forced, unpaid breaks from work. ${ }^{43}$

It is true to say, however, that union complaints did not persuade the employers to make many concessions. Despite the enlightened managerial strategy followed by some benevolent employers such as Seebohm Rowntree, the majority of companies were opposed to paying wages for work not done, the principle being "good pay for work, but no work no

38 The London Citizen, August 1926, p. 2.

39 The Workers' Union Record, May 1926, p. 15; The Amalgamated Engineers' Monthly Journal and Report, November 1919, p. 58.

40 See generally J. Mensch, "The Urban Workers' Need For Holidays", in: The Labour Magazine, March 1932, pp. 502-03.

${ }^{41}$ Minutes of Evidence, op. cit., p. 309. For the development of holidays with pay on the Continent, see S. G. Jones, "Work, Leisure and Unemployment in Western Europe between the Wars", in: British Journal of Sports History (forthcoming, 1986).

${ }^{42}$ Id. , "The Trade Union Movement and Work-Sharing Policies in Interwar Britain", in: Industrial Relations Journal, XVI (1985).

${ }^{43}$ For further elaboration, see Minutes of Evidence, passim. 
pay". ${ }^{44}$ Given the criterion of profit maximisation, schemes like holidays with pay, which increased the cost of production, were resisted, especially when the economy was in depression. Employers argued that paid holidays, by inflating the wage bill, exerted upward pressure on costs and hence squeezed profit margins. As one Derbyshire coal-owner commented: "Could anything be more absurd in these terribly difficult days than the proposal to grant a fortnight's holiday with full pay?" 45 Such a proposal was later considered to be "far too Utopian to be within the range of practical politics". ${ }^{46}$ Further, those businesses engaged in external trade such as textile mills were reluctant to grant concessions on the grounds that the measure would damage exports and so increase unemployment. ${ }^{47}$ In addition to this, there was also opposition to statutory initiatives to extend holiday benefits. The National Federation of Building Trade Employers, on the face of it sympathetic to the demand, argued that the issue should not be made the subject of regulation by legislation, "but should be dealt with, in the natural course of events, by those organised employers and operatives in the industry who best know the conditions". ${ }^{48}$ In fact, what the employers meant by the phrase "the natural course of events" appears to have been the time when they, and they alone, considered it practicable and reasonable to make the concession. Employers thus wished to retain their prerogative to manage.

In examining the approach of the employers it is discernible that arguments were articulated in such a way as to delay developments. As a result attitudes were inconsistent and policy often contradictory. The coal-owners thus had no coherent approach to the question. On the one hand, the Lancashire and Cheshire owners stated that the matter "was a national Question, and they were not prepared to take the lead in granting such a reform"; on the other hand, the Mining Association felt that the matter could only be worked out "by the process of local negotiation in the light of

44 Unity, February 1928, p. 137. Seebohm Rowntree refused to give evidence to the Committee on holidays with pay, as he thought the case needed no bolstering: "I should have thought it was pretty generally accepted that a holiday of some kind is desirable, and that if a holiday is given it must be with pay." Quoted in A. Briggs, Social Thought and Social Action: A Study of the Work of Seebohm Rowntree 1871-1954 (London, 1961), p 299.

${ }^{45}$ Quoted in J. E. Williams, The Derbyshire Miners (London, 1962), p. 788.

${ }^{46}$ Minutes of Evidence, p. 310.

47 Ibid., p. 129; Cotton Spinners' and Manufacturers' Association Minute Books, 193740, passim, Greater Manchester County Record Office, Manchester.

48 Minutes of Evidence, pp. 180-81; The National Builder, December 1936, pp. 163-64; April 1937, p. 298; November 1937, pp. 110-12. 
the varying conditions in the different districts". ${ }^{49}$ The truth of the situation was that the vast number of colliery-owners were against the provision. These delaying tactics were supported by the National Government the appointment of a committee of inquiry reflected the attitude of an administration who "did not wish to act against the opinion of many employers", and who wished to allow "industry, especially on the employers side in depressed industries, to have time to catch up to public opinion". ${ }^{50}$ In fact, by the time the Committee had reported, the employers were still in opposition. Although views were voiced revealing sympathy with the principle, the fact is that the employers' organisations were intransigent and clearly against implementation. It was argued that holiday pay would increase the wage bill, damage foreign trade, and interfere with management prerogatives. ${ }^{51}$ The argument was based on strictly economic grounds of business rationale: industrial efficiency, international competitiveness, labour costs, profit margins and managerial control. The consensus of the employers, expressed in committees of inquiry, sessions of Parliament and the ILO, and industrial negotiations, was one of opposition to holidays with pay. It was therefore left to organised labour to campaign for this much-needed reform.

\section{The holidays-with-pay campaign}

A feature of the developments before 1914 was the activity of the tradeunion movement. In 1897 the Amalgamated Society of Railway Servants gained a paid holiday of one week's duration (after five years of service) for all passenger guards, brakesmen and signalmen; whilst at about the same time the Typographical Association was pressing for a week's paid holiday. ${ }^{52} \mathrm{~A}$ few years later the TUC also made its first demands, when at the 1911 conference a resolution calling for appropriate legislation was carried

49 Minutes of the Lancashire and Cheshire Joint Committee and Joint Wages Board in the Mining Industry, 16 November 1936, Working Class Movement Library, Manchester; Minutes of Evidence, pp. 285-86.

50 A. V.S. Lochhead, "The Use of Advisory Bodies in the Industrial Relations Department of the Ministry of Labour", in: Advisory Bodies: A Study of Their Uses in Relation to Central Government 1919-1939, ed. by R. V. Vernon and N. Manserch (London, 1940), p. 293. See also Memorandum by the Minister of Labour, n.d., Prime Minister's Office Papers $1 / 218$, Public Record Office. This sidetracking was condemned by sections of organised labour, see Daily Herald, 24 February 1937; Daily Worker, 2 March.

${ }^{51}$ Report of the Committee on Holidays with Pay, pp. 28-33.

$52 \mathrm{Ph}$. S. Bagwell, The Railwaymen: The History of the National Union of Railwaymen (London, 1963), p. 180; A. E. Musson, The Typographical Association: Origins and History up to 1949 (London, 1954), p. 191. 
by a large majority.$^{53}$ The demand was again raised at a deputation received by Prime Minister Asquith on 15 February 1912; the union case was firmly advanced by the Parliamentary Committee of the TUC and Asquith assured the delegation that the matter would be given his consideration..$^{54}$ This meeting signified the embryonic stage of a movement which was to gain mass support and following in the years after the First World War.

In the immediate post-war period the trade unions launched their campaign for holidays with pay. It is perhaps indicative of the change in feeling that whilst in February 1917 the General Federation of Trade Unions criticised the trades councils for making such allegedly impossible demands as holidays with pay, by 1919 such a criticism had been largely dispelled..$^{55}$ For example, the Printing and Kindred Trades Federation was actively engaged in negotiations. Driven on by rank-and-file action in 1918, the Federation secured a national Hours and Holidays Agreement in the following year, which entitled employees to a week's holiday with pay after one year's service ${ }^{56}$ The provision was significant as it covered nearly all workers in the industry and was later described as "one of the greatest boons ever introduced". ${ }^{57}$ Interestingly enough, the claim for holidays with pay was made by many other unions, most notably the National Union of Railwaymen, the Workers' Union, the Miners' Federation of Great Britain, the National Transport Workers' Federation, and the United Textile Factory Workers' Association..$^{58}$ Moreover, the TUC pledged its support for the holiday-pay movement, and, perhaps most significant of all, important agreements were signed in the railway sector and boot and shoe manufacturing, for example. ${ }^{59}$ In spite of the slump of 1920 , when not

53 TUC, Annual Report, 1911, pp. 235-36.

s4 TUC Parliamentary Committee, Quarterly Report, March 1912, pp. 20-22, 27.

55 A. Clinton, The Trade Union Rank and File: Trades Councils in Britain, 1900-40 (Manchester, 1977), p. 102; General Federation of Trade Unions, Annual Report, 1919, p. 33.

56 Typographical Association, Quinquennial Delegate Report, June 1918, pp. 78-81; The Typographical Circular, April 1919, p. 7.

${ }^{57}$ H. S. Temple, "Trade Unionism in the Printing Industry", in: G. D. H. Cole et al., British Trade Unionism To-Day (London, 1939), p. 373. See also The Typographical Circular, July 1930 , p. 146.

58 National Union of Railwaymen, Decisions of the Special Conference on "After War" Matters, November 1917, MRC Mss 127/NU/4; The Workers' Union Record, December 1919, p. 7; Miners' Federation of Great Britain, Annual Conference Report, 1920, p. 120; The Railway Gazette, 6 February 1920; Cotton Factory Times, 27 August.

59 TUC Parliamentary Committee, 29th Quarterly Report, March 1918, p. 11; TUC, Annual Report, 1919, pp. 375-76; Scottish TUC, Annual Report, 1919, pp. 104-05; Bagwell, The Railwaymen, op. cit., p. 379; A. Fox, A History of the National Union of Boot and Shoe Operatives 1874-1957 (Oxford, 1958), pp. 362, 408-09. 
surprisingly the unions adopted an essentially defensive strategy of protecting existing agreements and conditions, the demand remained very much a live issue in the period leading up to the General Strike and beyond.

In 1923, for instance, a Joint Committee of Trade Unionists and Co-operators in the distributive trade placed the demand on the bargaining agenda. This led to a dispute between the Co-operative Wages Board, which represented the Co-operative Wholesale Societies, and the National Union of Distributive and Allied Workers concerning whether union members should have six or twelve days' summer holiday, in addition to customary and statutory entitlements. ${ }^{60}$ Although the matter was referred to arbitration, in some districts such as Fife the union balloted its members on a proposal to take strike action. ${ }^{61}$ Again in March 1924 the union was demanding that the holiday period at the Imperial Tobacco Company be increased. Kindred organisations having members in the employ of the company were approached, and the Workers' Union, the National Cigar Makers' and Tobacco Workers' Union, the National Union of General Workers, and the United Kingdom Operative Tobacconists' Association agreed to joint action. ${ }^{62}$ Moreover, in the same year a union deputation to the Home Office claimed "that all shop assistants should have an annual holiday on full pay of at least two consecutive weeks". ${ }^{63}$ This type of activity was reflected in the attitude of the distributive workers' industrial secretary, Joseph Hallsworth. In communication with the ILO in 1924 he suggested that "holidays with pay is one of the most important items we have in our collective agreements relating to wages and conditions of employment for commercial, and to some extent, for allied workers." ${ }^{64}$ As an active trade unionist and also later as President of the International Federation of Commercial, Clerical and Technical Employees, he was to remain an important figure in the struggle for paid holidays, eventually serving on the departmental committee, in 1937 and 1938.

It is difficult to resist the conclusion that a number of industrial organisations were taking the question seriously. As the secretary of the Nottingham branch of the National Federation of Building Trade Operatives pointed out, "The question of 'Payment for Holidays' has been occupying

60 File on holidays with pay, MRC Mss 70/3/15/3-12.

61 Daily Herald, 26 May 1923.

62 Memorandum dated 19 March 1924, MRC Mss 70/3/15/14. See also National Union of Distributive and Allied Workers, Annual Report, 1923, p. 7; 1924, p. 7; The New Dawn, 1923-24, passim.

63 The New Dawn, 12 April 1924.

64 J. Hallsworth to Mr Parlett, 18 February, MRC Mss 70/3/15/17. See also id., Protective Legislation for Shop and Office Employees (London, 1935), pp. 212-15. 
an important place of late in the discussions between various bodies of Employers and Employed." ${ }^{65}$ Further evidence of this can be found in 1924 when the conferences of the Miners' Federation of Great Britain and the Amalgamated Engineering Union called for agitation for an annual holiday with pay ${ }^{66}$ Naturally enough, the TUC upheld these decisions. The General Council in collaboration with the Labour Party Executive investigated the "demand for a recognised holiday, during which wages should continue to be paid", stressing the role organised labour would have to play in any move towards holidays with pay. ${ }^{67}$ This sentiment was followed shortly afterwards by an official resolution of support, carried at the Scarborough Conference of $1925 .{ }^{68}$

Rank-and-file trade unionists were also receptive to the idea. In Manchester in the mid 1920's the Corporation Employees' Central Committee, in conjunction with the borough Labour Party and the City Council Labour group, submitted a paid-holiday claim, which was turned down by the employers' side of the district Joint Industrial Council. ${ }^{69}$ Clearly, the Committee was in a militant mood, as without the cognizance or consent of the TGWU official machinery a ballot of the membership was taken on the question of a strike.$^{70}$ Although it is not known what became of this ballot, it is evident that this kind of action was not an isolated event. Thus in 1924 the Ministry of Labour failed to bring about a settlement in a holiday-pay strike of about 350 members of the National Union of General Workers at a factory in Stratford..$^{71}$ The usual procedure on such occasions was to remit the dispute to arbitration, and for those workers in the local-authority sector the Industrial Court was the adjudicating body. ${ }^{72}$ The point to stress is, however, that the publicity given to militant action almost certainly reinforced the case for holidays with pay. ${ }^{73}$ Furthermore, sectional de-

6s NFBTO Circular Letter, 20 December 1923, Circular Letters, Vol. 2 (1923), p. 251, cf. NFBTO Emergency Committee Minutes, 15 and 16 January 1924, University of Manchester Institute of Science and Technology Library.

o6 Times, 11 July 1924; AEU, National Committee Report, May 1924, pp. 78-79.

${ }^{67}$ Annual Holidays with Pay (Joint Research and Information Department of the Labour Party and the TUC, May 1924), MRC Mss 70/3/15/63.

${ }_{68}^{6}$ TUC, Annual Report, 1925, p. 529.

${ }^{69}$ Epitome of the Proceedings of the Workmen's Special Committee of the Manchester City Council, 28 May and 24 December 1925; Manchester Labour Party, 22nd Annual Report, 1925, pp. 21-22.

${ }^{70}$ Manchester City News, 9 January 1926; Sunday Worker, 14 March; Minutes and Record of the Meeting of the General Executive Council of the TGWU, 22 June, MRC Mss 126/T\&G/1/1/4.

${ }^{71}$ Daily Herald, 19 March 1924.

72 Holidays-with-pay file, MRC Mss 70/3/15/179-84.

${ }^{73}$ Interestingly, even the Coal Commission was in support. See Report of the Royal Commission on the Coal Industry (1926), p. 235. 
mands tended to influence the official union leadership, as when the request of the Public Utility Service Minority Movement was adopted by the London District Council of the National Union of General and Municipal Workers. ${ }^{74}$

In the years immediately after the General Strike the demand was a major feature of a number of industrial negotiations and agitations. From the TUC down to the smallest of unions the issue was elevated into the channels of industrial discourse. In the case of the TGWU, by 1927 reference was to be made to paid holidays "in all the future negotiations with Employers". ${ }^{75}$ Even the poorly organised such as the agricultural workers were claiming that "The man working on a farm is as much entitled to have a holiday with pay as any other class of workers or citizens." end of the 'twenties it is not too surprising to discover that various unions had made claims for paid holidays, many of them having appropriate clauses in their collective agreements. ${ }^{77}$ It is indeed a reflection of union commitment that in the first year of the following decade the three major national workers' organisations unanimously passed motions in favour of the holiday principle. ${ }^{78}$ If the question had once been a "huge joke", as one delegate recalled, there can be little doubt that by the 1930's it was taken seriously. The policy was again a feature of both official union and rankand-file activity.

Divisional committees in the engineering industry clearly considered the demand a material proposition. At talks between the Executive Council of the AEU and the employers in April and October of 1927, the Huddersfield and district delegates emphasised the importance of the discussions relating to holidays. ${ }^{79}$ Likewise, during the National Committee meeting the Hartlepool, Durham, Edinburgh, Fife and Newcastle divisions argued that longer holidays and payment for these should be sought. ${ }^{80}$ The following year formal talks on this demand commenced between the union and the Engineering and Allied Employers' National Federation. However, the employers delayed making any decision on the grounds that policy would

74 The Worker, 27 February 1926

${ }^{75}$ Minutes and Record of the General Executive Council of the TGWU, 27 May 1927, MRC Mss $126 / T \& G / 1 / 1 / 5$.

76 The Workers' Union Record, November 1927, pp. 16-17. See also Minutes of a joint meeting of the TUC General Council and Labour Party Executive, 27 March 1929, TUC Archives, London.

7 Industrial News, 19 November 1929.

78 TUC, Annual Report, 1930, pp. 410-11; Scottish TUC, Annual Report, 1930, p. 171; General Federation of Trade Unions, Annual Report, 1930, pp. 24-29.

79 AEU, Monthly Journal, May 1927, p. 11; November, p. 8.

80 AEU, National Committee Report, May 1927, pp. 74, 99. 
have to be made in private before the demand was included on the bargaining agenda. The union leadership was eventually informed by letter of their opposition, no detailed reason being given except a statement that, "without going into the merits involved, [ . . ] the Board still considers the present is not an opportune time to raise this question." ${ }^{11}$ Even so, a paid holiday was now part of the engineers' programme. In 1929 this was formalised when a section of the engineers' charter called for statutory holiday pay, though this was not achieved until the late 1930's. ${ }^{82}$

Despite the defeat of 1926 the rank and file continued to make progressive demands. Even in the mining industry the injustice of holidays without pay was a well-publicised theme. The Miners' Minority Movement, in contrasting the long holidays of the coal-owner Viscount Tredegar with those of the workers, clearly thought there was a need for paid holidays, as did other groups. ${ }^{83}$ The programme of the Textile Workers' Minority Movement included a call for a "fortnight's annual holiday with full pay for all cotton workers"; the distributive workers demanded 12 days' holiday on full pay after 12 months' service; the Furnishing Trades section a week's paid holiday; and the fur workers two weeks' holiday with pay ${ }^{84}$ As already noted, it appears that rank-and-file action influenced the deliberations of union officials. Thus, soon after the Railwaymen's Minority Movement had drafted a case for holiday benefits, based on the premise that "a holiday with no money is useless", the union leadership drew up a new programme for the lower-paid grades and shopmen, which reiterated the earlier militant demands. ${ }^{85}$

Industrial action was again the feature of the militant approach. In the Leeds clothing trade, for instance, the energy of the local activists was directed at the retention of a paid-holiday agreement. In 1930 a holidayswith-pay scheme came into operation in the clothing trade as the result of a settlement between the Tailors and Garment Workers' Union and three Employers' Federations. ${ }^{86}$ Despite this, companies like Burton failed to introduce a scheme, which inevitably met with resistance. During 1932 the

\footnotetext{
81 AEU, Monthly Journal, April 1928, p. 15; June, p. 11.

82 AEU, National Committee Report, May 1929, p. 103; AEU, The Engineers' Charter (London, 1932), p. 7.

83 The Mineworker, 13 July 1928.

${ }^{84}$ Textile Workers' Minority Movement, The Struggle of the Lancashire Textile Workers (London, 1929), p. 15; The Distributive Worker, January 1928, p. 1; The Chisel, January 1929, p. 2; The Fur Worker, March 1930, p. 3.

${ }^{85}$ The Worker, 13 December 1929; National Union of Railwaymen, Agenda and Decisions of the Special General Meeting, 24 October 1930, MRC Mss 127/NU/4.

86 A. Conley, "Clothing Trade Agreements and Holiday Payments", in: The London Trade Union Handbook (London, 1930), pp. 35-37.
} 
management of one of the chain's outlets in Leeds was approached by a section of the workforce with a series of demands, culminating in a number of important concessions. ${ }^{87}$ The Burton workforce was further motivated the next year by two industrial disputes: at the local factory of Prices a lightning strike of 4,000 employees resulted in them getting their holiday pay; and at the Schneider clothing factories in London, 1,000 girls struck work in a dispute over holiday gratuity. ${ }^{88}$ The workers at Burton were now of the opinion that they too should receive a paid holiday. Although the usual channels of negotiation were by-passed, because local representatives of the union fell short of local demands and even failed to attend meetings over the issue, it is clear that some advances were recorded. ${ }^{89}$

The evidence suggests that both the official union movement and the militant rank and file were still engaged in the campaign in the late 1920's and early 1930's. It is also true to say that socialists in the political world were interested in this question, supporting the industrial workers' claims whenever the opportunity arose. In 1929 the principle was endorsed by the House of Commons, when Ernest Winterton's Annual Holiday Bill received a favourable second reading, but unfortunately there was no further progress on the pretext that consuiltation was required with the TUC and the National Confederation of Employers' Organisations..$^{90}$

Despite the failure on the legislative front certain concessions were in fact made by the Labour Government of the day. There had been pressures within the party to introduce some kind of provision: the Left Wing Movement, which had the support of the Labour Left, had called for "recognised holidays with full pay", whilst the Scottish Independent Labour Party mooted the idea of a month's paid holiday, and the Research Department was asked to prepare a memorandum on the matter.$^{91}$ Consequently, action was taken in August 1929 when nearly 100,000 workers in state-owned industrial establishments benefited from a Government decision to grant one week's holiday pay. Will Thorne, General Secretary of the

87 Burton's Red Leader, 9 September 1932.

${ }_{88}$ The Garment Workers' Voice, July 1933, p. 2; Boroughs of Poplar and Stepney and East End Advertiser, 5 August.

${ }^{89}$ Burton's Red Leader, 27 September. In demanding holiday pay, militants failed to acknowledge that the Montague Burton, Hudson Road factory had one of the largest holiday-savings clubs in the world. See the Montague Burton Archives, newscuttings books, Leeds Archives Department, Acc. 1951/36, 128.

90 Hansard (Commons), Fifth Series, CCXXXI, cc. 2421-506, 15 November 1929; CCXL, c. 594, 19 June 1930.

91 National Left Wing Provisional Committee, The Left Wing: Its Programme and Activities (London, n.d. [1927?]), p. 18; Times, 9 January 1928; Labour Party Executive Committee Minutes, 7 February, Labour Party Archives, London. 
General and Municipal Workers, commented that the "reform was overdue, and it should have been granted years ago, but we could hardly expect any real concessions from Tory or Liberal Governments. It has taken the Labour Government to do it, and the workers will appreciate the fact." 92 Although there were complaints from building workers about anomalies in the Government's scheme, the general response was one of enthusiasm. ${ }^{93}$ Indeed, there was a flood of resolutions demanding the extension of the paid-holiday principle and considerable correspondence on the subject. The National Union of Sheet Metal Workers and Braziers, the AEU, the Gorton United Trades and Labour Council, and the National Union of Foundry Workers all started to lobby the Labour Party; and at the same time a number of unions agreed to follow joint action in submitting a claim for 12 days' holiday with pay to the Co-operative Wholesale Society. ${ }^{94}$ Also interesting are the moves which were being made at local level, for example, at Salford. ${ }^{95}$

In the years between 1918 and 1933 the trade unions managed to shape some kind of holidays-with-pay campaign. By presenting their case to employers, the state, and indeed their own members, the trade unions were able to influence the climate of opinion, so essential if gains were to be made. In a sense this was the first phase of the campaign when many sections of the community came to accept the justice of the union's claims. The policies and actions of labour represented a kind of ideological penetration of established mores about the holiday custom, by which it was agreed that a holiday without wages was really no holiday at all. After the failure of the General Strike, the campaign, far from languishing, entered a more dynamic phase, being raised at all levels of the industrial-relations system from workshop to international conference.

\section{The fruition of the union campaign}

With the recovery of the economy from about 1933, and the consequent regeneration of union membership, finance and organisational resources,

92 Daily Herald, 28 August 1929.

93 NFBTO Emergency Committee Minutes, 12 and 13 March 1930; NFBTO, Annual Conference Report, 1930, p. 151.

44 Labour Party Executive Committee Minutes, 28 September 1929; Minutes of a joint meeting of the TUC General Council and Labour Party Executive, 23 October; Report of a Conference of Unions affiliated to the National Co-operative Conciliation Board, 7 October, MRC Mss 70/3/15/47.

95 See Salford City Labour Party Executive Committee Minutes, 20 December; Salford City Labour Party Delegate Committee Minutes, 8 January 1930, Working Class Movement Library; Minutes of the Salford City Council, 22 January; Salford City Reporter, 24 January 
the campaign was ready to take on its final phase. The union leadership was soon claiming that the campaign should be stepped-up and made "one of the burning questions of the day" ${ }^{96}$ Ernest Bevin similarly suggested that there should be "the organisation of a national movement for the purpose of securing a statutory holiday of at least two weeks in each year for all workers, with the payment of full wages". ${ }^{97}$ In his words, the campaign for holidays with pay was a "vital issue". ${ }^{98}$ From 1934 to 1937 resolutions of support were thus passed in successive years by many unions, including the AEU, the NFBTO, and the National Union of Scottish Mine Workers. ${ }^{99}$ Furthermore, as well as the progress made by the TUC and its affiliates, smaller unions such as the National Amalgamated Union of Life Assurance Workers, labour women and district unions began to consider the question. ${ }^{100}$ And, in fact, there were some successes: for example, union pressure resulted in a number of firms granting a holiday on full pay in celebration of George V's Silver Jubilee in 1935. ${ }^{101}$

The unions also thought that some kind of international regulation was required. The British labour representative on the governing body of the ILO, Arthur Hayday, declared the need for a convention.

At the unanimous request of the British trade union and Labour movement I have from time to time urged upon Governments and employers through the machinery of the International Labour Office the urgency for a convention giving holidays with pay that could be universally ratified. ${ }^{102}$

96 General Federation of Trade Unions, Quarterly Report, 30 June 1933, pp. 8-12; TUC, Annual Report, 1933, pp. 277-79.

${ }^{97}$ Times, 15 July 1933; TGWU, Minutes and Record of the Proceedings of the Biennial Delegate Conference, 1933, p. 32; The Record, August 1933, p. 14.

98 The Record, June 1936, p. 263.

99 AEU, National Committee Report, 1934, p. 106; 1935, pp. 13-14; 1936, p. 155; NFBTO, Annual Conference Report, 1934, pp. 95-98; 1935, p. 109; 1936, p. 109; P. B. Long, "The Economic and Social History of the Scottish Coal Industry 1925-1939, With Particular Reference to Industrial Relations"' (Ph.D., Strathclyde University, 1978), p. 237.

100 National Amalgamated Union of Life Assurance Workers, holidays-with-pay file, MRC Mss 141/10; The Labour Woman, February 1935, p. 25; Summarised Report of the 5th Annual Conference (1934-5) of Representatives of Unions Catering for Women Workers, 1935, p. 21; National Conference of Labour Women, 1935, p. 11; there are numerous examples of district unions seeking paid holidays, for example, Rochdale Labour News, November 1936, p. 7.

101 See TUC General Council Minutes, 27 February 1935; London Trades Council, 76th Annual Report, 1935, p. 17; [A. Pugh,] Men of Steel, by One of Them: A Chronicle of Eighty-Eight Years of Trade Unionism in the British Iron and Steel Industry (London, 1951), p. 509.

102 Hansard (Commons), Fifth Series, CCCXVIII, c. 759, 27 November 1936. 
The question had first been canvassed in 1919 and 1920 by the Swedish workers; subsequently, it was provisionally placed on the agenda of conference in 1927, 1931, 1933 and 1934, but was dropped from the proceedings. By 1935, however, the ILO was supporting the idea of a paid holiday. ${ }^{103}$ Even so, the British Government was against the adoption of a convention on the grounds that international regulation would be impossible to enforce due to the complexities associated with uniform implementation. ${ }^{104}$ This stance had a lot to do with the opposition of the British employers' representatives on the international holidays-with-pay committee, who deemed it inadvisable to place the question on the 1936 agenda. ${ }^{105}$ In spite of this, further discussion did take place in 1936, leading to the adoption of a convention providing six working days' paid holiday each year. In the opinion of the British trade unionist Herbert Elvin this was the most extensive convention of the conference: "It covers all workers. It is also the most important. It adds to the dignity of life and makes a contribution to the modern problem of the right use of leisure." 106

The question was also recognised in the House of Commons when a private member's bill, introduced by Guy Rowson, Labour MP for Farnworth, would have made it a legal obligation of every employer to grant an annual holiday with pay of eight consecutive days. Despite a Conservative blocking amendment, the general consensus of Parliamentarians, especially in Socialist circles, was one of support. ${ }^{107}$ The bill received a second reading and went to a Standing Committee for further discussion. This gave the TUC General Council the opportunity to "seek information on the extent to which the Prime Minister would be prepared to support the Annual Holiday Bill". ${ }^{108}$ A Committee was formed to organise a deputation to the PM, Stanley Baldwin, which was received in early 1937 . Baldwin outmanoeuvred the deputation by suggesting that a tripartite Committee of

103 International Labour Office, Holidays with Pay Report (Geneva, 1935).

104 Hansard (Commons), Fifth Series, CCCXVIII, c. 759.

105 The British employers were represented by Thomas Ashurst (Cotton Spinners' and Manufacturers' Association), William Henry Barritt (Allied Association of Bleachers, Dyers, Printers and Finishers) and John Smith (Shipbuilding Employers' Federation). It must be added, however, that the stance of the British Government was not simply a mere reflection of the opposition waged by the employers. After all, governments act as a broker of all sectional interests, and for political and electoral reasons cannot afford to ignore totally the voice of organised labour. Even so, the Government was broadly sympathetic to the employers and, as suggested, delayed legislative and other initiatives. 106 International Labour Conference Report, 22nd Sitting, 23 June 1936, p. 433.

${ }^{107}$ For the debate, see Hansard (Commons), Fifth Series, CCCXVIII, cc. 725-808, 27 November.

108 TUC General Council Minutes, 23 December. 
Inquiry be set up. ${ }^{109}$ In the mean time Rowson's Holiday Bill was amended in Committee by the imposition of a clause removing its obligatory character; the bill was disowned by Rowson, and this gave the Government the chance to drop the bill altogether. ${ }^{110}$

It is perhaps even more significant that with the upswing of the economy those militants who had been unemployed started to find work again. From about 1935 workshop struggles were in evidence as the rank and file organised themselves into a shop-stewards' movement, and it was they who harnessed the interest in and nurtured the growing mass support for paid holidays. With the formation of the National Aircraft Shop Stewards' Council in 1935 strident demands were made for "statutory holidays with pay". ${ }^{111}$ As the nation began to re-arm and the aircraft industry prosper, the workers clearly thought that they were entitled to a share of the resulting prosperity by way of better conditions of employment.

The demand was also taken up by local shop-steward groupings. Towards the end of 1934 there developed a grass-roots movement in South-East London representing the workers of two large electrical engineering firms, Siemens Brothers and Johnson \& Phillips. From its inception the clarion call of the movement was the need for paid holidays. ${ }^{112}$ The shop committees at these two firms took the lead, and in May 1935 they held a joint meeting which decided to launch a campaign for holidays with pay; leaflets were sent to neighbouring factories, pointing out that rank-and-file organisation was required and that all local workers should join and participate in "the practical struggle for paid holidays". ${ }^{113}$ For instance, a mass meeting was organised at Woolwich Town Hall in June 1936, when over 1,500 workers from five factories pledged their support. ${ }^{114} \mathrm{~A}$ further meeting of fifty delegates representing several thousand workers made it clear that constitutional means would be the basis of the campaign, but if these failed "direct action" would have to be used. ${ }^{115}$ With increasing activity, including a deputation to the local MP for Greenwich, it became clear that

${ }^{109}$ Note of a Deputation from the TUC received by the Prime Minister, 15 February 1937, Prime Minister's Office Papers 1/218. See also Memorandum headed deputation, 15 February, MRC Mss 126/EB/HP/1/3; TUC General Council Minutes, 24 February. $" 10$ G. Rowson, "Holidays with Pay", in: New Fabian Research Bureau Quarterly, Summer 1937, pp. 26-31. See also Ministry of Labour Papers 10/53/1R/280.

13 Aircraft Shop Stewards' National Council, The Aircraft Workers' Case (London, n.d. [1936?]), p. 15.

112 See The Journal of the Siemens Shop Stewards' Committee, October 1934, pp. 2-3.

${ }_{113}$ Ibid., June 1935, p. 4; The Tribune, 2 July 1937.

114 The Journal of the Siemens Shop Stewards' Committee, No 26 (August 1936?), p. 7.

115 Conveyor, February 1937, p. 4. 
the demand could not be ignored any longer. ${ }^{116}$ It was finally announced that the Cable Makers' Association had confirmed that one week's paid holiday would be granted to 20,000 cable workers. ${ }^{117}$ There was great joy and it is interesting that the May Day procession in London included more than one banner hailing the victory. ${ }^{118}$

Militant tendencies in the AEU had also given shape to a more forceful approach. In the first report of the shop committee at D. Napiers Ltd, Acton, emphasis was thus placed on the demand, and "packed and enthusiastic" mass meetings were held, leading to the successful imposition of an overtime embargo. ${ }^{119}$ This militant policy had wider implications: at a national meeting of the AEU some divisional committees urged that strike action be taken, and though this was not accepted, definite calls were made for 14 days' holiday with pay. ${ }^{120}$ It seems that the Engineering and Allied Employers' National Federation took notice of these developments for they were pressurised at not one, but two levels. Firstly, firms who were affiliated to the Federation were subjected to persistent demands by their workforce - this was the case in South-East London, Napiers, and aircraft companies such as Blackburns, Hawkers, Handley Page, De Haviland and Fairy Aviation - and, as the director of the employers' organisation reported, an increasing number of federated firms were making concessions. ${ }^{121}$ Secondly, the official leadership of the union, in the form of the Executive Council, continually raised the subject during negotiations with the employers. ${ }^{122}$ Eventually, at a meeting between the Engineering Joint Trades Movement and the Employers' Federation, an agreement was signed granting one week's holiday with pay. ${ }^{123}$ As a number of commentators suggested, this gain was intimately related to the vast number of union applications made in all parts of the country.

It was certainly the case that the trade-union rank and file were an important force in the campaign for holidays with pay. They provided the conviction, they influenced official union policy, they organised mass meet-

\footnotetext{
116 It is interesting to note that the MP, Sir George Hume, must have been in a very ambiguous position, as he was also a director of Siemens.

${ }_{117}$ The Tribune, 25 June 1937.

118 In the film Advance Democracy (a co-operative film produced in 1938) the scene about the 1937 May Day clearly shows the paid-holiday banner and contingent.

119 New Propellor, March 1937, p. 10; April-May, p. 3.

120) AEU, National Committee Report, 1937, pp. 149-50, 190.

${ }_{121}$ New Propellor, August 1937, p. 2; E. Wigham, The Power to Manage: A History of the Engineering Employers' Federation (London, 1973), pp. 143-44.

122 AEU, Monthly Journal, June 1937, p. 223.

${ }_{123}$ Ibid., August, p. 300; AEU, National Committee Report, 1938, pp. 43-46.
} 
ings, petitions and deputations, and they even resorted to strike action, as was the case in Leicester and the Potteries. ${ }^{124}$ At Swindon, for example, a snowstorm failed to dampen the enthusiasm, and a demonstration organised by the Railway Shopmen's Federation, embracing many unions and attended by about 3,000 workers, affirmed the need for militant action. ${ }^{125}$ In this way they were able to make holidays with pay a "real" issue, which by 1937 was "regarded by every clear-thinking person as an elementary right which every worker should enjoy". ${ }^{126}$ From 1937 the leadership of the broad labour movement, at times prompted by grass-roots feeling, consolidated these developments and were able to make some significant gains.

The Labour Party hit upon a novel way to publicise the question. During the summer months of 1937 a Seaside Campaign for holidays with pay was organised. About 72 seaside resorts were approached by the party's National Executive Committee, and it was hoped that not less than twenty meetings would take place each week. ${ }^{127}$ The campaign began in June and was led by the Labour Party big four of Clement Attlee, Arthur Greenwood, Herbert Morrison and Hugh Dalton; a leaflet was printed which quickly sold over half a million copies; and by the end of July, 30 seaside resorts had been covered. ${ }^{128}$ Reports indicate that well-attended meetings were the rule and the sale of literature was well above the average: "From Berwick on the East Coast to Morecambe on the West, at every important resort round the coast, at all places where Britain's most fortunate citizens are enjoying their annual respite from work, Labour is carrying on its great campaign for Holidays with Pay." 129 There can be few doubts that the seaside drive was successful, with over 150 meetings, the distribution of one million leaflets and the display of thousands of pictorial posters. ${ }^{130}$ The demand for a universal legal obligation to paid holidays was therefore a plank in Labour's "Immediate Programme", and indeed deemed a priority

124 For further details of these two strikes, see The Leicester Mercury, 17 August 1935; Leicester Evening Mail, 17 and 20 August; Evening Sentinel (Stoke on Trent), August 1937, passim.

125 The Swindon Advertiser, 5 March 1937. The railway shopmen were awarded one week's leave with pay in August 1937, see The Railway Review, 27 August.

126 Johnson \& Phillips Shop Stewards' Journal, No 10 (April 1937?), p. 11.

127 Minutes of the Labour Party Campaign Committee, 19 May 1937.

${ }^{128}$ Holidays with Pay [Labour Party Leaflet No 54] (1937); Minutes of the Labour Party Publicity, Research and Local Government Committee, 22 July; Minutes of the Labour Party Campaign Committee, 26 July.

${ }^{129}$ Labour, August, p. 279; The Record, August, p. 5.

130 Labour Party, Annual Conference Report, 1937, pp. 23, 59. 
in the next session of Parliament. ${ }^{131}$ Despite the defeat of Labour's Holidays with Pay Bill in November 1937, the campaign was now in its final stages, and even Government procrastination and management obstruction had little effect.

During 1937 and 1938 holidays with pay was, thus, the clarion call of organised labour. Up and down the country labour groupings were presenting their case, be it through the leftist Unity campaign or the more moderate trades councils. ${ }^{132}$ Yet, it was the TUC who compiled "information representative of opinion from the Groups" and, of course, presented it to the Amulree departmental committee, arguing persuasively for statutory enactment. ${ }^{133}$ As a result of this kind of pressure, many gains were made: aside from legislation, voluntary paid-holiday agreements were signed by engineering workers, railway shopmen, miners, iron and steel workers, potters, and other categories of workers. However, the campaign did not end here. The TUC General Council re-appointed its specialist sub-committee, which maintained a close liaison with those trade unionists who had served under Lord Amulree, whilst textile operatives and building-trade workers continued to press for an agreement of their own. ${ }^{134}$

\section{An evaluation of union policy}

This paper has claimed that the trade unions were instrumental in the introduction of holidays with pay. The sources provide evidence that

131 Labour Party, Labour's Immediate Programme (London, 1937), p. 6; Minutes of the First Joint Sessional Meeting of the Parliamentary Labour Party and National Executive Committee, 26 October 1937. Significantly, as Elizabeth Durbin's excellent study of the Labour Party's economic thought in the 1930's has shown, party intellectuals like Evan Durbin were "“very keen' on a universal statutory period of holiday with pay each year". E. Durbin, New Jerusalems: The Labour Party and the Economics of Democratic Socialism (London, 1985), p. 247.

132 See National Unity Campaign Committee, The Unity Campaign (London, n.d. [1937?]), p. 4; A. Horner, Trade Unions and Unity (London, 1937), p. 6. Minutes of a delegate meeting of the London Trades Council, 11 March and 8 April 1937; Minutes of the South Shields Trades Council, 20 July and 31 August; Bolton and District United Trades Council, Annual Report, 1937, p. 3; Leicester and District Trades Council, Year Book, 1938, p. 10. Trades councils, such as the one at Leigh, also held meetings with the local Labour Party over this issue. Minutes of the Leigh branch of the Bolton Operative Cotton Spinners' Provincial Association, 1 July 1937, Manchester University Library.

${ }_{133}$ E. Bevin to National Officers, Transport House, 13 April 1937, MRC Mss 126/ EB/HP/1/13; TUC General Council Minutes, 28 April. The evidence of the TUC was published in two pamphlets, Holidays with Pay: The T.U.C. Policy (London, 1937) and Holidays For All (London, 1938).

134 TUC General Council Minutes, 23 November 1938. For the textile operatives, see S. G. Jones, "The Lancashire Cotton Industry and the Development of Paid Holidays in the Nineteen-Thirties", in: Transactions of the Historic Society of Lancashire and Cheshire (forthcoming, 1986). 
without continued trade-union pressure, concessions would have been delayed if not refused. The official leadership and the rank and file were the leading actors in the campaign throughout the inter-war period: the question was discussed and publicised at all levels of the labour movement, and influence was brought to bear through workplace negotiations, official representation, and direct action. The role played by organised labour was important insomuch as holidays with pay were granted mainly in the form of voluntary collective agreements between masters and men. Put simply, it is a misconception to regard the Holidays with Pay Act of 1938 as the natural inheritance of the campaign. As already suggested, the legislation itself applied to wage-regulating bodies, and so covered only a minority of the British workforce. Moreover, in some areas the act actually retarded existing arrangements. Certainly, the Parliamentary secretary of the National Amalgamated Furnishing Trades Association had some justification in regarding the provisions "with suspicion", "as a window-dressing stunt to be produced at election time". ${ }^{135}$ All this is to be expected, of course, for the British trade unions had a preference for collective bargaining as opposed to state legislation. ${ }^{136}$ In brief, the act was a belated recognition of the widespread concession of paid holidays industry by industry.

To be sure, union activity was not the only element in these concessions. In the first place, those firms following a progressive industrial-welfare policy introduced the necessary benefits without union pressure or coercion, though this may have been to wean workers away from trade unionism. ${ }^{137}$ It is also interesting that many progressive groups outside the ranks of organised labour were advocates, and even the Daily Express had its own campaign. ${ }^{138}$ But perhaps most important of all, holidays with pay were conceded at favourable points in the trade cycle, the boom of 1918-20 and the industrial recovery of the later 1930's. Obviously, business was in a position to afford industrial reforms of this kind during economic prosperity. However, this point should not be pushed too far. In fact, employers remained intransigent during a period of increasing trade

135 National Amalgamated Furnishing Trades Association, Monthly Report, August 1938, p. 25. See also Daily Herald, 14 July; Daily Worker, 18 July; Challenge, 21 July. 136 See A. Fenley, "Labour and the Trade Unions", in: The Labour Party: An Introduction to its History, Structure and Politics, ed. by Ch. Cook and I. Taylor (London, 1980), p. 52.

137 See S. G. Jones, "The British Labour Movement and Working Class Leisure, 19181939" (Ph.D., Manchester University, 1983), pp. 151-53.

138 Daily Express, 5 and 29 April 1938. For liberal supporters of the campaign, see Welfare Work in Industry, by Members of the Institute of Industrial Welfare, ed. by E. T. Kelly (London, 1925), p. 114; Conference on Christian Politics, Economics and Citizenship, Leisure (London, 1924), pp. 18, 109. 
buoyancy between 1932 and 1937, whereas they signed agreements during the trade depression of 1937-38. The main benefit bestowed on organised workers by favourable economic conditions was increased membership and greater negotiating strength. Furthermore, militant action had a greater chance of success under such conditions. In other words, the unions were able to bargain for holidays with pay with more resolve and likelihood of success in the immediate post-war period and from about 1933, not because of the favourable attitude of employers, but because of their own improved bargaining position. The question still remains, however, to what extent did the unions attach importance to the policy of paid holidays?

The first point to make is that the unions were less concerned with the minutiae of policy than with the fundamental questions arising from the overall impact of unemployment and industrial stagnation - rationalisation, finance, membership levels and, most important of all, wages. It is suggestive that in one local poll holidays with pay was only the eleventh most popular question, below such reforms as the minimum wage, unemployment insurance and an extension of health services, though above public ownership and workmen's compensation. ${ }^{139}$ In particular, the demand for paid holidays was never considered as important an issue as the maintenance of wages. As the work of Stephen Shaw has shown, the protection and improvement of wages remained the primary union objective. Whenever there was a threat to wages and earnings, other policy options tended to be relegated. ${ }^{140}$

Having made this point, it should be recalled that holidays with pay was regarded as significant by many trade unionists, simply because of the hardships associated with the unfinanced break from work. Although paid holidays cannot be divorced from wage setting, as a number of employers appreciated, it is true to say that a campaign around the holiday issue was more likely than wages to create solidarity between different union groupings. The multiplicity of unions and categories of workers made it difficult for a united stance over wages because interests were sectional and disjointed. Yet, the campaign for paid holidays was strong, because it "naturally reaches out, not only to every class of worker in the factory, but in a simple, direct line to every wife and mother in the home."141

139 Gloucester Labour News, February 1939, p. 1. One survey undertaken by the Scottish TUC found that 49 out of 59 unions appreciated the importance of the question, Scottish TUC, Annual Report, 1938, p. 60.

$140 \mathrm{~S}$. Shaw, "The Attitude of the Trades Union Congress Towards Unemployment in the Inter-War Period" (Ph.D., Kent University, 1979), especially pp. 67-107.

141 Daily Worker, 1 April 1937. 
For some workers it may have been the case that leisure time was taking on a greater importance in their lives. As some economic historians have asserted, a proportion of the gains in employment conditions were taken by workers in the form of more leisure rather than increased income. ${ }^{142}$ This leisure preference can certainly be detected in the case of a representative number of smaller unions. The National Union of Foundry Workers, the Union of Post Office Workers, the Typographical Association and the National Society of Painters were beginning to pronounce that holidays with pay and other leisure benefits were just as important, if not more so, than increased wages. ${ }^{143}$ Also interesting is the fact that a marginal critique of the work ethic and the wage nexus evolved during the special conjuncture of the inter-war years. No doubt this was connected with the prevailing levels of unemployment and the greater subordination of labour to the work process through the spread of scientific management (the Bedaux system) and rationalisation of industry, but it also had much to do with the demand for qualitative improvements in leisure, including paid holidays. ${ }^{144}$

Some commentators, such as John Aplin, the National Industrial Officer of the Independent Labour Party, protested that the unions only paid "lipservice" to the principle of holidays with pay. ${ }^{145}$ However, the evidence provided here suggests that this was far from the case. Detailed studies of particular unions have shown that the question was constantly raised in internal discussion and in negotiations with employers. Industrial, general and craft unions alike undoubtedly ranked holidays with pay as one of the main objectives, though not as significant as the wage round. By 1937, as H. S. Gordon elaborated, "Holidays with pay as a practical and immediate objective have captured the imagination of millions of trade unionists and Labour Party supporters." 146 Moreover, the fact that workers were prepared to take industrial action is testimony enough to the importance attached to the question.

Once awards had been made the response was always very enthusiastic. In the pottery trade a paid holiday was said to have "reached both the hearts and pockets of the workers more than any other Award in the living

${ }^{142}$ E. H. Ph. Brown and M. H. Browne, A Century of Pay (London, 1968), p. 208.

${ }_{143}$ National Union of Foundry Workers, Journal and Report, July 1933, p. 4; The Post, 2 March 1935, p. 190; The Typographical Circular, January 1937, p. 1; National Society of Painters, Monthly Journal, February, pp. 36-37.

144 Jones, "The British Labour Movement and Working Class Leisure", op. cit., pp. 382-94.

145 The New Leader, 6 August 1937. See also Daily Herald, 16 April 1927; Cotton Factory Times, 9 August 1935; A. Bullock, The Life and Times of Ernest Bevin, I: Trade Union Leader 1881-1940 (London, 1960), p. 601.

146 Labour Monthly, September 1937, p. 560. 
history of the industry", whilst in the heavy steel industry it was regarded as the "biggest reform [ . . .] since the eight-hour day was established in 1919", and in the building industry as "an historic moment in the struggle of the building trade movement for the betterment of the building trade operative". ${ }^{147}$ Likewise, trade-union leaders, such as Harry Edwards of the dockers and John Little of the engineers, stressed that paid holidays was one of the most significant improvements of the day. ${ }^{148}$ As the Central Board of the Co-operative Union commented, "The gain to the workers of holidays with pay, insofar as this has been obtained without statutory backing, is probably one of the most solid and valuable of gains to the workers in recent years." 149 If indeed it was a significant gain, then it was the contribution of the trade unions which made such a gain possible in the first place. There are numerous examples which point to the "pioneering work", the "agitation", the "considerable effort", and the "insistence" of the unions in the campaign for holidays with pay. ${ }^{150}$ The shopworkers' union, for instance, continually drew attention to their own advances, and, as the holiday-pay card of the Wigan and District Weavers' Association succinctly expressed it, "Your Trade Union Secured Holidays With Pay!"151

\section{Concluding comments}

The aim of this paper has been to outline the main elements in the development of paid holidays, and the role played by organised labour. It emerges that a major reason for the concession of holiday pay relates to the actions and energies of the trade unions. It is, of course, true that some workers were able to by-pass the problems created by holidays without pay by institutionalised saving - though only then at times of full employment and, moreover, that some generous employers introduced appropriate schemes, but the weight of evidence suggests that the unions were respon-

147 General Federation of Trade Unions, Annual Report, 1937, p. 18; Manchester Guardian, 19 January 1938; R. Coppock, circular letter, December 1942, NFBTO Circular Letters, Vol. 21 (1942), p. 177.

148 Minutes and Record of the Proceedings of the Biennial Delegate Conference of the Transport and General Workers' Union, 1937, pp. 41-42; Gloucester Labour News, April 1939, p. 8.

149 Co-operative Union, Annual Congress Report, 1938, p. 39.

150 The Record, June 1937, p. 282; The Journal (Organ of the Post Office Engineering Union), 13 August; National Union of Foundry Workers, Journal and Report, April 1938, p. 5; The Labour Woman, June, p. 84.

151 The Shop Assistant, 19 October 1929, 4 July 1931, 21 May 1932, 21 August 1937, 23 April and 7 May 1938; Wigan and District Weavers, Winders, Reelers and Beamers' Association, Holiday Pay Card, Lancashire Record Office DDX 1123/446. 
sible for much of the progress made. Gains of this kind clearly improved the quality of workers' lives, though there was no inevitability about the implementation of paid holidays. Despite the silence of historians on this matter, it is important to acknowledge that such improvements were the site of struggle and contestation between the interests of labour and capital. Although the major gains were made during times of trade prosperity, there is no reason to believe that agreements were made simply because of rising profits. To be conclusive about the relationship between profit levels and the introduction of paid holidays it would be necessary to carry out a number of econometric tests based on the profit margins of individual firms and industries, labour costs, estimated changes in productivity, the state of market demand, and a number of other variables. Even if this were possible and a positive correlation between profits and the date of agreements were found, it would still not invalidate the assumption that labour played a major role in their introduction.

Holidays with pay, as suggested, ranked as an important trade-union objective. From the mid 1930's activism at the workplace helped to mould an articulate campaign. Using a number of channels of influence, the unions shaped the campaign into one of "practical politics". Supported by all sections of the labour movement, employers were less able to resist the pressure for paid holidays. Even the delaying tactics of a Government committee of inquiry and subsequent Parliamentary activity failed to placate the workers' demands.

On the eve of the Second World War the process of establishing a paid holiday as a universal social right was all but complete. By early 1940 about 4.5 million wage-earners (in addition to many more salaried staff) benefited from agreements. This was an increase of three million in three years, thanks to the union-sponsored campaign. Not all workers had been granted a paid holiday, but the principle of financial support for holidays was by then accepted. The contribution of the labour movement, and in particular the trade unions, to the process was crucial. As Andrew Robertson of the British Institute of Management concluded, "It was the trade unions who were largely responsible for making sure that the majority of British workers get an annual holiday." 152

152 A. Robertson, The Trade Unions (London, 1965), p. 11. 